\title{
Proposal the Use of Alternative Materials for Construction of an Alternative Low- Cost Sunlight Collecting System to Latin American Market
}

\author{
Spacek, A. D. ${ }^{1-3}$, Santana, M. V. F de ${ }^{4-5}$,Mota, J. M. ${ }^{1-3}$, Biléssimo, L. D. ${ }^{1}$, Ando Junior, O. H. ${ }^{2}$, Malfatti, C. F. ${ }^{3}$ \\ ${ }^{1}$ Departament of Mechanic and Automation \\ SATC, Beneficent Association of Santa Catarina Coal Industry \\ Street Pascoal Meller, 73. Criciúma-SC (Brazil)
}

Phone/Fax number: +55 48 3431-75.50, e-mail: anderson.spacek@ satc.edu.br, joao.neto@ @atc.edu.br, luciano.bilessimo@satc.edu.br

${ }^{2}$ Departament of Renewable Energies

UNILA, Federal University of Latin American Integration

Av. Sílvio Américo Sasdelli, 1842. Foz do Iguaçu-PR (Brazil)

Phone/Fax number: +55 45 3576-73.07, e-mail: oswaldo.junior@unila.edu.br

${ }^{3}$ School of Engineering

UFRGS, Federal University of Rio Grande do Sul

Av. Osvaldo Aranha, 103. Porto Alegre-RS (Brazil)

Phone/Fax number: +55 51 3308-31.29, e-mail: celia.malfatti@ufrgs.br

${ }^{4}$ Hidroelectric Power Plant

BAESA, Energética Barra Grande S/A

Rua Madre Benvenuta, 1168. Florianópolis-SC (Brazil)

Phone/Fax number: +55 48 3331-0000, e-mail: marcus.santana@cscenergia.com.br

${ }^{5}$ Hidroelectric Power Plant

ENERCAN, Campos Novos Energia S.A.

Rua Madre Benvenuta, 1168. Florianópolis-SC (Brazil)

Phone/Fax number: +55 48 3331-0000, e-mail: marcus.santana@cscenergia.com.br

\begin{abstract}
This paper presents a study on the potential use of fixed collectors consist of prismatic lenses that capture sunlight for indoor lighting. The proposed research is to develop an alternative system to capture sunlight, aimed at lighting environments with natural light directly, maintaining thermal comfort without cost functional, using a source of clean and inexhaustible energy. Currently the technology to capture the natural light is not developed in Latin American, but is already exploited in other countries so quite efficiently reaching present yield greater than $90 \%$ transmission of natural light due to its high quality finish. This market the application of this technology is in quite small considering the high cost of implementation for point light added to the import taxes can reach US\$1,500.00 (in Brazil). The main focus of the work is to develop a product that through the study and development of materials from raw materials derived from municipal solid waste can provide a low cost solution with adequate income to reality where the product is applied. The work requires the design of a prototype of the capture system using the materials developed and the validation of the same real situation of application for a period of twelve months so predicting system behaviour verification in various conditions and to verify the behaviour materials developed front inclement weather and aging. As a result of this preliminary study it was found that the costs of materials to be used for the development of alternative products do not reach even $20 \%$ of
\end{abstract}

the current selling price. Therefore, the development and industrialization of this low-cost sunlight collecting system result in a social nature of technology accessible to all. Consequently, will benefit dealers, who can distribute it poor communities, improving the quality of life of these people and thus reduce non-technical losses. Therefore, with the focus in the popularization of technology in Latin American, presenting this as a low cost solution, the work aims to develop an alternative to natural light harvest, using recycled and reused materials, making it an environmentally friendly product, good efficiency and sustainable.

\section{Key words}

Overhead lighting Municipal Solid Waste; Solar collector and Recycled Materials.

\section{Introduction}

Electrical energy is vital for economic development, it's necessary increase the offer to accompany the demand expansion $[1,2]$. Along with the increase of the offer are sought of sustainable solutions with low 
environmental impact. In this context, there is the strategic goal of diversification of energy sources with increase in alternative sources participation [3, 4]. However, high costs of implementing the Green Energy and the fact that technologies associated with this concept have an income below the conventional forms of generation are barriers [4]. Therefore, in order to facilitate dissemination of Green Energy is increasingly sought to increase the generation of system efficiency and the use of renewable energy, such as the use of sunlight, which is an abundant and inexhaustible resource [4].

Corroborating to include the alternative energy sources as alternative, this work aims to use sunlight direct for interior lighting to replace the artificial lighting that consumes electricity during the day contributing to the conservation and energy efficiency. But, it's necessary analyze deeply, because besides the problem of lack of energy there is the shortage of reserves of materials. Aiming the sustainability this paper proposes the design of a direct sunlight capture system made from raw material processed urban solid waste for lighting customized environments. Consequently contributing to technological development, electric energy efficiency improving and to conservation of natural resources in Latin America.

The relevance of this project is emphasized by studies that indicate that Latin America has a great potential of renewable energy sources with Brazil as one of the countries with the highest energy potential of the planet. Brazil has around $4.5 \mathrm{kWh} / \mathrm{m}^{2}$ to $5.5 \mathrm{kWh} / \mathrm{m}^{2}$ of solar irradiation, which corresponds to a much higher level of irradiation then countries like Germany, Spain and Portugal $[5,6,7,8]$. And with regard to environmental issues, we seek to minimize the environmental impacts of tons of urban solid waste deposited daily in the environment [9]. According to the National Survey of Basic Sanitation conducted by the Brazilian Institute of Geography and Statistics (IBGE, 2002), show that in Brazil the urban sanitation systems collect about 150 tons of urban solid waste (MSW) per day. And of this total about $63.6 \%$ clean out waste in garbage dump, $18.4 \%$ in controlled landfills and only $13.8 \%$ use not controlled landfills [10].

\section{State of the Art: Solar Capture System}

Globally, the capture technology of sunlight is consolidated and is industrialized by specialized companies mainly at United States and Spain. These industries use in their manufacturing processes high value material with excellent optical properties, like silver and the high purity aluminum for example. These equipment's can light indoors using the natural light with outputs higher than $90 \%[11,12]$. The lighting system consists of three elements, as can be seen in Fig. 1, the dome is on the outside of the building and has the function of receiving the sunlight and direct it into the tube. The reflective tube has highly reflective inner lining, he is responsible for transporting the natural light reaching the dome and forward it by reflection to the diffuser lens, this makes the scattering of sunlight illuminating the environment as a whole $[11,12]$.

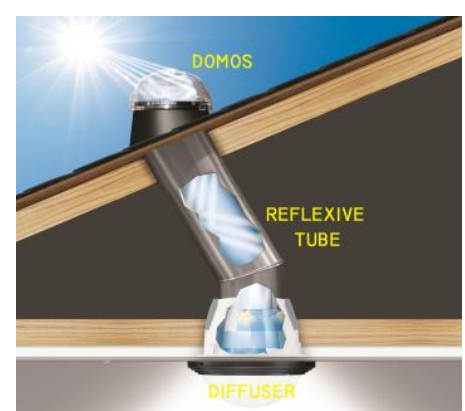

Fig. 1. - Tubular lighting system [12]

The existing product in the countries of 1 st world is built with high value materials of excellent quality and superior energy efficiency. These products with high cost and high importation taxes become an inaccessible technology to much of Latin-America population. Trying to make this technology accessible to all and adapted to Latin America, it proposes the development of a similar system, but manufactured from raw material processed MSW, and aiming, in this way, a final cost of about 10 times smaller.

It is known that the use of MSW is a less noble raw material which implies a reduction in output of the final product but based on previous studies it is believed that it is feasible to obtain reflectivity level of about $45 \%$ ensuring the applicability and massive product acceptance. Reaffirming the applicability of the research, there have high levels of solar radiation, for example, Brazil is a country with one of the best solar radiation levels, where low solar radiation in Brazil is about $40 \%$ higher than the sunniest place in Germany, which is currently the country that excels in power generation through photovoltaic panels [13].

\section{A. Domos}

These elements are made of polyester and glass. A deep knowledge of lenses is necessary to capture light, having to reconcile its transparency for the transmission of rays with mechanical force to protect it from impact and weather and also provides the system sound insulation characteristics and low thermal conduction $[11,12]$

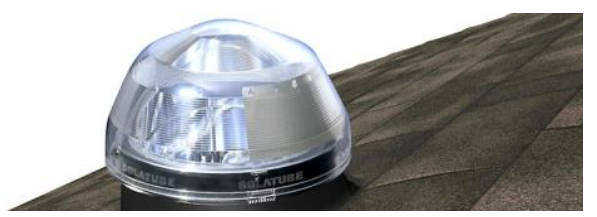

Fig. 2. - Types of domos [12]

Each company has its type dome, with construction characteristics and specific materials, seeking a better use in capturing and direction of sunlight, making the project has longer lighting time, taking advantage of even the smallest angle of incidence of the sun $[11,12]$. 


\section{B. Reflexive Tube}

The reflective tube shown in Figure 12 are made of aluminum having its highly reflective inner silver surface treated via a process called physical vapor deposition (PVD) and have the function of directing rays received by the diffuser lens, the phenomenon that determine its functionality is the internal reflection. According to Sears (1985) a beam of light that reaches one end of a tube will be totally internally reflected, this being trapped inside the bar, the bar or tube is called light pipe [14]. As used tubes require a very high reflectivity, companies have developed technology to prevent reflective loss as much making the same reach $99.7 \%$ [12].

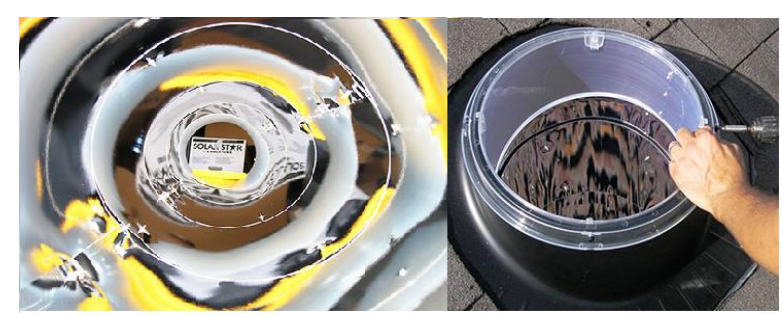

Fig. 3 - Inside view of the highly reflective tube [12]

\section{The Diffuser}

The diffuser lens is the last element of the tubular lighting system, it serves to spread the light received from the reflective tubes and illuminates the interior of the environment with quality, and in addition, it also contributes to the thermal insulation and acoustic of the project. This lens is made of polymeric material (acrylic), as can be seen in Figure 4, made to improve the diffusion of incoming rays, thus contributing to the use of natural lighting, which also provides the thermal and acoustic insulation that can be molded in various formats adapting this modeling environmental aesthetics [11, 12].

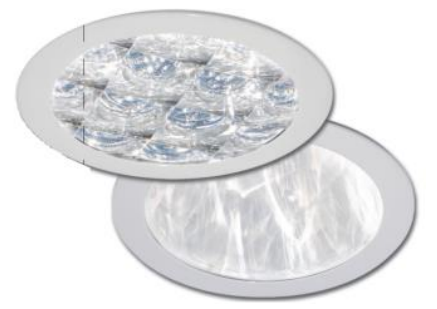

Fig. 4 - Diffuser Lens [12]

\section{Proposal for Solar Collectors Making Materials Processed using Solid Waste - MSW}

The proposal is based on a commercial construction similar system presented above, but constructed with MSW materials. MSW in Latin America is a problem because the large part is intended to dumpsites without any treatment or environmentally friendly destinations. According to the Brazilian Association of Public Cleaning Companies and Special Waste (ADRELPE), in 2013 the urban solid waste generation in Brazil was 76,387,200 tons indicating an increase of $4.1 \%$ over the previous year and exceeding the rate of population growth that was $3.7 \%$ in the same period [15].
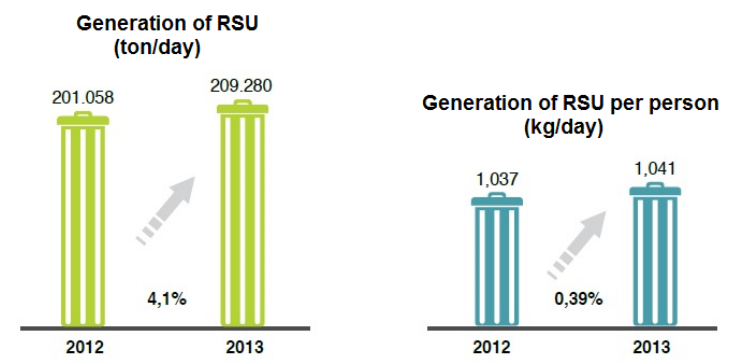

Fig. 5 - The urban solid waste generation in Brazil [15]

These data indicate that more is needed not only the incentive to reduction of waste generation, but also investment in public policies to encourage the recycling of waste generated and particularly in the massive reuse of these materials for manufacturing thus reducing the extraction of natural resources and consequent accumulation of garbage. In the case of the recycling process of aluminum, plastic, paper and glass are four types of waste having significant involvement in the country recycling activities as can be seen in Figure 6.

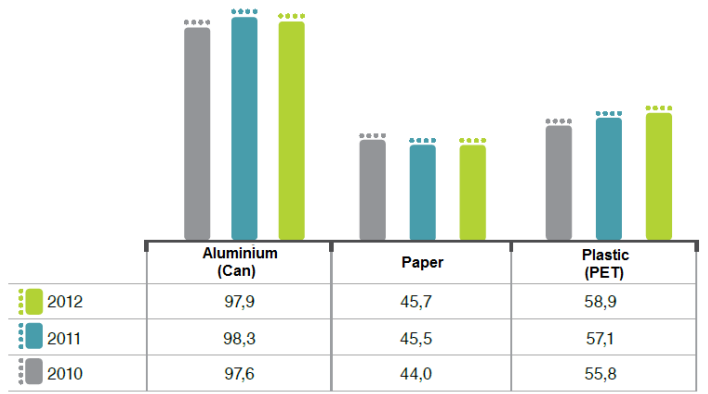

Fig. 6 - Main products of municipal waste recycled in Brazil and their recycling rates [15]

Poly Ethylene Terephthalate (PET) is a polyester, the thermoplastic polymer used in large scale for the manufacture of bottles for soft drinks, water, juices and oils [16]. The PET provides high impact resistance and supports contact with aggressive agents becoming a product widely used in food industry, medicine and hygiene. As seen in Figure 6, the PET ranks the second position in recycling in Brazil and has been growing over the years. The PET Brazilian Association in their sense reinforces that since 1994 the PET recycling rate is increasing over the years [17].

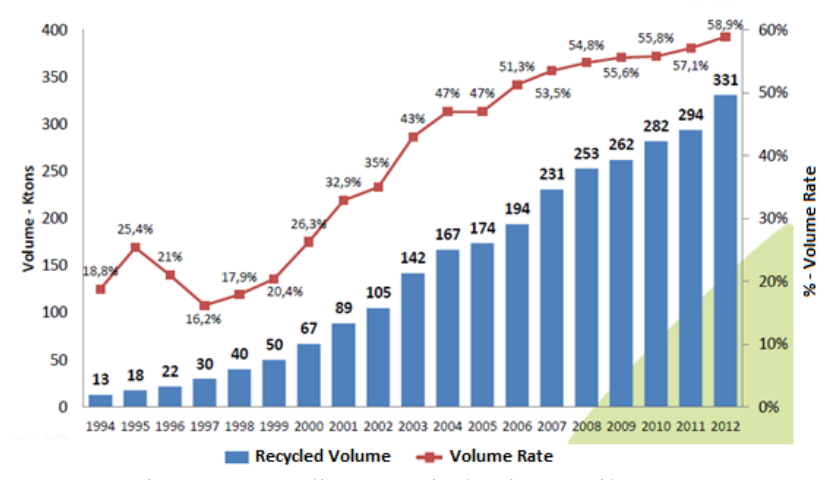

Fig. 7 - Recycling PET index in Brazil [17] 
Along with the growth of recycling, it's seek to allocate the raw material recycled for industrial applications and reduce consumption of natural resources. There are currently numerous applications already given to recycle PET (RPET) through the craft for decoration and other specific applications. Other example is the use of (RPET) into building materials and the reinforcing fiber of the cement [18].

In a detailed study of the mechanical properties of RPET, Lopez et al. (2014) concluded that reprocessing PET causes a degradation but which nevertheless is compensated by polymerization reactions in the recycling process and thus keeping these processes results in mechanical characteristics very close to the original [19, 20].

Starting by the reflective tube, the proposal is build the direct sunlight system using RPET as their base material, it's presents as a viable solution because it takes advantage of the high strength characteristics and low cost of the raw material RPET as compared with the raw materials of the finest technologies used today, like aluminum.

Table I. - Characteristics of the reflexive tube - Solatube [12]

\begin{tabular}{|c|c|c|}
\hline Properties & Unit & Value \\
\hline Thickness & $\mathrm{mm}$ & 0.5 \\
\hline Maximum width & $\mathrm{mm}$ & 1250 \\
\hline Composition & & $\mathrm{Al} 99.85$ \\
\hline Mechanical Properties & & \\
\hline Ductile tension & $\mathrm{Mpa}$ & $160-200$ \\
\hline Resistance to traction & $\mathrm{Mpa}$ & $140-180$ \\
\hline PVD layer & & PVD Ag \\
& & 99.95 \\
\hline Optical Properties & & $\geq 98$ \\
\hline Total light reflection & $\%$ & $<6$ \\
\hline Light loss on reflection & $\%$ & \\
\hline
\end{tabular}

The data presented in Table I demonstrate that the material used in the commercial reflective tube is aluminum and has high tensile strength characteristics and ductile strain. Moreover, as mentioned before, the reflection inside the tube comes to have a value greater than $98 \%$ because the same has a silver layer deposited on the inner aluminum surface by the spray method.

The material proposed in case the RPET presents lower mechanical resistance property then the aluminum used in the original product. However, this inferiority is not a characteristic that technically prevents the proposal, since the application of it takes place in conditions that do not require large mechanical stress of the material and therefore does not carry a risk of damage.

The solution of RPET construction to the pipe becomes interesting in many respects, but the problem is that the very lower reflectivity than the commercial material halts its use without the addition of some other material that can improve the property to reflect light.
To ensure the necessary reflectivity and consolidate the proposed use of RPET is suggested the surface application of recycled aluminum with high reflection inside the tube of plastic bya a technique called vacuum metallization technique. This application has been gaining strength in the market mainly in the automotive industry that needs to reduce part weight of vehicles to ensure their performance and thus replace metal parts by metalized plastic parts giving them better look and finish [21]. In Figure 8 is shown an image of some parts that passed through metallization process. Among the advantages of this process are the safety and the low environmental risks when compared with other similar processes. This process generally makes the deposition of thin films of $0.5 \mathrm{~mm}$ to $5 \mathrm{~mm}$ materials such as aluminum, copper, stainless steel and chromium on the surface of materials such as plastic, metal, glass, paper and other materials [22]. The vacuum metallization process is similar to the vaporization processes used today, where the part is placed in an environment from which air is removed and vaporized metal being deposited on the piece [21, 22].

According to the literature presented above, the vacuum metallization process is not efficient when it considers the mechanical resistance, in other words, the adhesion is not sufficiently strong to ensure that mechanical efforts can't release the deposited layer. However, as the proposed application of reflective layer inside don't suffers mechanical stress, it completely fulfills the applicability necessities [21, 22].

The use of aluminum as the material to be deposited is even more property considering that recycled aluminum that can be used in this application because the recycled aluminum is considered an infinite recycling material and which does not lose its properties in the recycling process [23].

As mentioned before the recycling of aluminum by the Brazilian industry is well known for its important indexes. The recycling of aluminum cans in 2011 came to the brand of 248,700 tons being superior to many other countries as shown in Figure 8.

\begin{tabular}{r|c|c|c|c|c}
\hline & 2007 & 2008 & 2009 & 2010 & 2011 \\
\hline Brasin & $96,5 \%$ & $91,5 \%$ & $98,2 \%$ & $97,6 \%$ & $98,3 \%$ \\
\hline Japajo & $92,7 \%$ & $87,3 \%$ & $93,4 \%$ & $92,6 \%$ & nd \\
\hline Argentina & $90,5 \%$ & $90,8 \%$ & $92,0 \%$ & $91,1 \%$ & nd \\
\hline Estados Unidos & $53,8 \%$ & $54,2 \%$ & $57,4 \%$ & $58,1 \%$ & $65,1 \%$ \\
\hline Média Europa & $62,0 \%$ & $63,1 \%$ & $64,3 \%$ & nd & nd \\
\hline
\end{tabular}

Fig. 8 - Recycling rate of aluminum cans [24]

These data support the use of recycled aluminum for the internal plating reflective tube is something interesting, applicable and environmentally friendly because it does not require the extraction of natural resources. In this case bauxite have a direct impact on energy consumption to obtain the raw material since the electricity consumption in recycling is about $90 \%$ compared to energy expended to produce aluminum from natural resource extraction. [24]

Regarding the reflectance of the deposited material is necessary a experimental evaluation to verify the efficiency in the transmission of light for the proposed application being. However, according to Pinner \& Simpson (1971) the deposited aluminum can reach a reflectance of $88 \%$ to $94 \%$ for visible light [25]. 


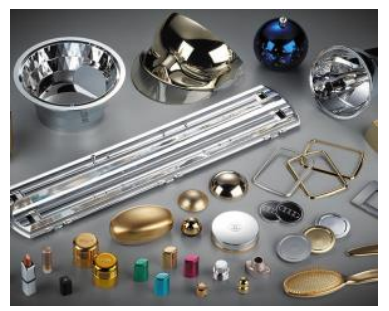

Fig. 9 - Metallic parts obtained for Vacuum Metallization [26]

To the reflective tube, the proposal is to be implemented the construction of the structures of the RPET tube having inside an aluminum deposited by vacuum metallization to ensure that light conduction from the external environment to the interior of the building. With respect to geometries, initially the construction can be part of a circular lamp with diameter and thickness geometry following test results. Finally, it's considered the best mechanical properties and the required reflectivity.

To the domos is also proposed a material derived from MSW with the characteristic of transparency to ensure that light does not undergo amplitude reduction lowering the output of the assembly. In addition, it is expected that this material has sufficient hardness to resist a surface risks. In Table II is shown the specifications of a product commercially distributed and which serves as a parameter for choosing the alternative material derived from MSW.

Table II. - Commercial Domos Features [11]

\begin{tabular}{|c|c|c|c|}
\hline \multicolumn{4}{|c|}{ Specifications (Domos) } \\
\hline Point charge & $12 \mathrm{~kg}$ & $\begin{array}{c}\text { Light } \\
\text { transmission }\end{array}$ & 0.81 \\
\hline Distributed load & $150 \mathrm{~kg} / \mathrm{m}^{2}$ & Solar factor & 0.77 \\
\hline $\begin{array}{c}\text { Surface } \\
\text { hardness }\end{array}$ & $6.5 \mathrm{mohs}$ & $\begin{array}{c}\text { Ultraviolet } \\
\text { Transmission } \\
\text { Coefficient }\end{array}$ & 0.56 \\
\hline $\begin{array}{c}\text { Thermal } \\
\text { transmittance }\end{array}$ & $2.8 \mathrm{w} / \mathrm{m}^{2}-$ & $\begin{array}{c}\text { Acoustic } \\
\mathrm{m}\end{array}$ & $30 \mathrm{~dB}$ \\
\hline
\end{tabular}

In some commercial luminaries, the dome is constructed of glass with thermal treatment, and in other cases with acrylic with ultraviolet treatment. For this proposal, the best option is the use of recycled glass as it also appears quite often in the setting of global recycling.

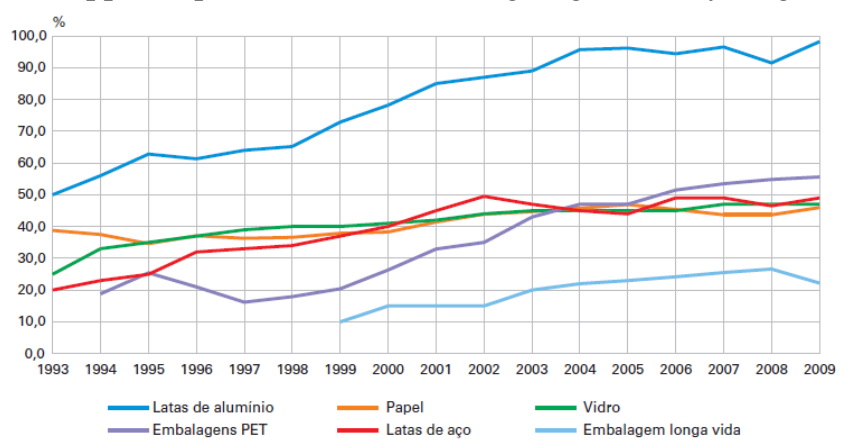

Fig.10 - Proportions of recycled materials in Brazil [27]
Other motive to include glass in the proposal is its infinite recyclability while maintaining the properties. However, you must ensure that as previously mentioned, it keeps the property of good impact resistance preventing its surface from being damaged and reducing the ability of conduct light. Besides that, another peculiarity of glass makes it interesting in this application, its high refractive index that aids directing light into the reflective tube when the solar position is unfavorable [28]. In Table III is shown the characteristics of glass reaffirming its choice as the proposed material for the domes.

Table III. - Glass Features [28, 29]

\begin{tabular}{|c|c|c|}
\hline Properties & Unit & Value \\
\hline Refractive index & $\mathrm{W} / \mathrm{m} . \mathrm{K}$ & 1,7 \\
\hline Thermal Conductivity & $\%$ & 85 \\
\hline $\begin{array}{c}\text { Transmission of solar } \\
\text { radiation }\end{array}$ & $\mathrm{Kg}$ & 170 \\
\hline Flexural strength & $\begin{array}{c}500 \mathrm{~g} \text { ball } \\
\text { falling } \\
2 \mathrm{~m}\end{array}$ \\
\hline Impact resistance & & \\
\hline
\end{tabular}

It's necessary to evaluate what is the best geometry tor the domos to ensure the best use of natural light at all times of the day.

Finally, after captured by the domes, directed by all reflective, the light reaches the diffuser which is responsible for its direction within the environment to be illuminated as equally as possible ensuring efficient equipment.

In case the material of the diffuser proposed to replace the used acrylic consolidated products can be used RPET having known characteristics presented in this work. This part of the luminary is not the most important part because what will determine the ambient light is the geometry and how it will be constructed to distribute light within the environment.

\section{Experimental Prototype}

In order to obtain an indication of the technical feasibility of a lighting environment by reflection sunlight, a small-scale prototype has been developed with the proposed materials or similar, as can be seen in Figure 11. The dome was built in tempered glass, the reflective tube was constructed with a thickness of $100 \mathrm{~mm}$ plastic tube coated inside with a reflective film (60\% efficiency) and the diffuser was built in polycarbonate.

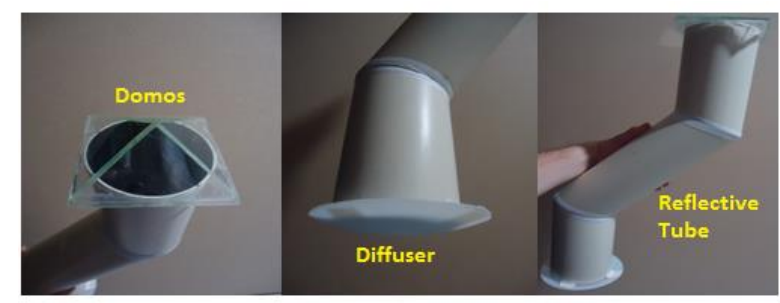

Fig. 11 - Prototype of direct sunlight lamp 
To validate the prototype, as shown in Figure 12, a controlled environment was developed on a scale according to NBR15215-4: 2005 to validate the prototype, which is completely enclosed by simulating an environment to be illuminated where it was possible to obtain data necessary to determine the technical feasibility of the proposal.

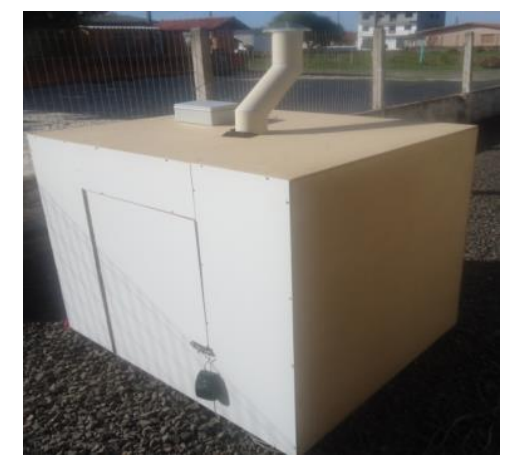

Fig. 12 - Validation Structure with controlled environment

Using a light meter measurements were performed as required by Brazilian standard ISO / CIE 8995-1: 2013, which determines the amount and location of the points to be measured to ensure that the results represent reality. The results are shown in Table IV and bring the illuminance information of the measurements inside and outside the validation box.

Table IV. - Validation results

\begin{tabular}{|c|c|}
\hline Measuring site & $\begin{array}{c}\text { Average Illuminance } \\
\text { (Lux) }\end{array}$ \\
\hline Externally & 540 lux \\
\hline $\begin{array}{c}\text { Internally in the center of } \\
\text { the box }\end{array}$ & 220 lux \\
\hline Efficience & $40,74 \%$ \\
\hline
\end{tabular}

\section{Results and Discussions}

As shown quite succinctly, the proposed system has strong technical indications that is possible to illuminate the interior of the environment (validation framework) from the acquisition of external light (solar) and using materials with some resemblance to the here suggested. The proposal would need to pass to a second stage where it will be held the project the geometry of the parts of the system as well as deepening of the properties of materials to build the most efficient system possible, which will certainly provide better results than the $40 \%$ obtained the prototype presented. It is also important to remember that the product certainly suggested using recycled materials will not achieve the $98 \%$ of efficiency, but still bet that with lower yields but also lower cost can increase the amount of fixtures thus compensating for this deficiency.

Analyzing the commercial point of view, the approximate cost of acquiring a marketed lighting point is approximately U\$ 1,058.00 including import duties and it is believed that to build the product with the materials proposed the cost will reach about U\$ 200.00 which is not even $20 \%$ of the product produced by the current manufacturers
On the other hand, analyzing the environmental point of view the proposal has a great sustainable appeal because of the production of a product through the reuse of the waste generated daily by the population will reduce the waste amount and will also help in reducing the use of natural resources. In addition, saves energy primarily in recycling because the reprocessing employes less energy and the use of natural light for illumination of environments during periods of the day save energy too.

\section{Conclusion}

Daily thousands of tons of waste are produces and discarded without an environmentally friendly destination, and often incorrectly causing environmental damage. Therefore, it is necessary to take this raw material (MSW) adding value sustainably. Today in Latin America, we walk slowly towards sustainability and reuse of materials.

The proposed product with its strong characteristics is a eco-friendly product which is currently heavily discussed worldwide in view of the effects that the abuse of natural resources and depreciation of the environment. This feature still requires a international certification, like, for example, PROCEL seal efficiency.

Thus, this work contributes to technological advances and the range improvement of new uses of RSU's. By developing a customized and adapted product to the reality of Latin America contributing to the conservation of energy and natural resources through the use of recycled materials resulting in a product of low cost, small and accessible to the general population, massifying production and further increasing reducing waste and energy consumption.

Besides the issue of natural resource conservation, waste reduction, energy consumption reduction, respect for the environment, it can be said that if the government invests in the implementation of these project in isolated communities, the product gains even with characteristic product of a social nature.

\section{Acknowledgement}

This project is being developed for under BAESA e ENERCAN R\&D program regulated by ANEEL (39363314/2015). The authors would like thank to the BAESA and ENERCAN for supporting and facilities. The research presented, is in patent registration request phase in Brazil.

\section{References}

[1] Aksanli, B.; Rosing, T.S.; Monga, I, "Benefits of green energy and proportionality in high speed wide area networks connecting data centers," Design, Automation \& Test in Europe Conference \& Exhibition (DATE), 2012, vol., no., pp.175,180, 12-16 March 2012. doi: 10.1109/DATE.2012.6176458

[2] Sithan, M.; Loi-Lei Lai, "Application of green technologies in developing countries - Reduced carbon emission and conservation of energy," Power and Energy Society General Meeting, 2011 IEEE, vol., no., pp.1,7, 24-29 July 2011. doi: 10.1109/PES.2011.6039665 
[3] Smith, N.; McCann, R., "Investigation of a Multiple Input Converter for Grid Connected Thermoelectric-Photovoltaic Hybrid System," Green Technologies Conference, 2012 IEEE, vol., no., pp.1,5, 19-20 April 2012. doi: 10.1109/GREEN.2012.6200938

[4] Singh, R.; Gupta, N.; Poole, K.F., "Global green energy conversion revolution in 21st century through solid state devices," Microelectronics, 2008. MIEL 2008. 26th International Conference on, vol., no., pp.45, 54, 11-14 May 2008. doi: 10.1109/ICMEL.2008.4559221

[5] LANDIM, Ana Luiza Pinto Ferreira; AZEVEDO, Lizandra Prado de. O Aproveitamento Energético do Biogás em Aterros Sanitários: Unindo o Inútil ao Sustentável. BNDES Setorial, Rio de Janeiro, n., p.59-100, mar. 2008.

[6] COLLE, S.; PEREIRA, E. B. Atlas de Irradiação Solar do Brasil. Brasília: Inmet/Labsolar, 1998.

[7] CHRISTANTE, L. A Eletricidade Subiu no Telhado. Unesp Ciência, São Paulo, v. 33, p. 18-25, ago. 2012.

[8] MAPA DA ENERGIA SOLAR. Disponível em < http://www.electronica-pt.com/ index.php/content/view/272/203/>. Acesso em: 15 jun. 2013.

[9] LEMEA, Brazilmarcio Montagnana Vicente et al. Techno-economic analysis and environmental impact assessment ofenergy recovery from Municipal Solid Waste (MSW) in Brazil. Elsevier: Resources, Conservation and Recycling. , p. 8-20. 2014.

[10] POLAZ, Carla Natacha Marcolino; TEIXEIRA, Bernardo Arantes do Nascimento. Indicadores de sustentabilidade para a gestão municipal de resíduos sólidos urbanos: um estudo para São Carlos (SP). Engenharia Sanitária Ambiental, São Paulo, v. 14, n. 3, p.411420, jul. 2009.

[11] ESPACIO SOLAR, Catalogo Espacio Solar iluminação natural Disponível em: <http://espaciosolar.com/fichas.htm>. Acesso em: 6 Jan. 2013.

[12] SOLATUBE, Catálogo Solatube iluminação natural - Disponível em: <http://www.solatube.com/es/productcatalog.htm>. Acesso em: 5 Jan. 2013

[13]CHRISTANTE, L. A eletricidade subiu no telhado. Unesp Ciência, São Paulo, v. 33, p. 18-25, ago. 2012.

[14]SEARS, F.W. Física 4, ondas eletromagnéticas, ótica e física atômica, Rio de Janeiro: LTC, 1985.

[15] Associação Brasileira de Empresas de Limpeza Pública e Resíduos Especiais (abrelpe). Panorama dos resíduos sólidos no Brasil. São Paulo: 2014. 114 p.

[16] MAKKAMA, Supawee; HARNNARONGCHAI, Wanlop. Rheological and Mechanical Properties of Recycled PET Modified. Elsevier: Energy Procedia., p. 547-553. 2014.

[17] ABIPET, Censo da reciclagem no Brasil. - Disponível em < http://www.abipet.org.br/index.html?method=mostrarDownloads\&ca tegoria.id=3

[18] GE, Zhi et al. Properties of plastic mortar made with recycled polyethylene. Elsevier: Construction and Building Materials. , p. 682-687. jan. 2014.

[19] LOPEZ, María del Mar Castro et al. Assessing changes on poly (ethylene terephthalate) properties after recycling: Mechanical recycling in laboratory versus postconsumer recycled material. Elsevier: Materials Chemistry and Physics. p. 884-894. 2014.

[20]SILVA, Talita de C.; MIRANDA, Leila Figueiredo de. Estudo Comparativo das Propriedades do Poli (Tereftalato de Etileno) Virgem e Reciclado. São Paulo: ., 2005. 24 p.

[21]K. de BRUYN et al. Study of pre-treatment methods for vacuum metallization of plastics. Elsevier: Surface and Coatings Technology, p. 710-715. 2013

[22] ANDRITSCHKY, Matin; PISCHOW, Kaj. Mass production of thick copper vacuum metallization on plastic parts. Elsevier: Vacuum, p. 1269-1273. 2008.

[23]ABAL - Associação Brasileira do Alumínio. Disponível em: <http://www.abal.org.br/sustentabilidade/reciclagem>. Acesso em: 22 fev. 2015.

[24]ABAL - Associação Brasileira do Alumínio. Relatório de Sustentabilidade 2012. São Paulo, 2012. 66 p.

[25]PINNER, S. H.; SIMPSON, W. G. Plastics: Surface and Finish. London: Butterworth \& Co (publishers) Ltda, 1971. 249 p.

[26] Kolzerbrasil - Referência Mundial em Metalização. Disponível em: <http://www.kolzer-brasil.com/>. Acesso em: 22 fev. 2015.

[27]IBGE - Instituto Brasileiro de Geografia e Estatística. Indicadores de Desenvolvimento Sustentável. Rio de Janeiro: 2012. 350 p.

[28]CALLISTER, W. D. Jr; RETHWISCH, D.G. Ciência e Engenharia de Materiais: uma introdução. Rio de Janeiro: LTC, 2009.
[29]Garante Vidros, Catálogo técnico - Disponível em: < http://www.garantevidros.com.br/downloads/cat_tec_garante.pdf >. Acesso em: 01 Mar. 2013. 